\title{
Who Owns Tonga: Dialogues with Sefita Hao'uli, Kalafi Moala, and Melino Maka
}

\section{Abstract}

"Who owns Tonga?" asked Sefita Hao'uli. "We do. The people," I quickly pitched back. But do we really? Quietly I second guessed myself after blurting out an idealistic reply. It might have sufficed the correct response in a liberal democracy where by one general election registered voters elected all their members of parliament. But in the Kingdom of Tonga's 2014 election year the dread squatting on my conscience murmured the monarchy and nobility owned Tonga, while ordinary people leased meagre pieces from the upper class for a price.

What social and economic cost did the country pay for not having a liberal democracy? By having nine nobles' seats in parliament where thirty-three title and estate holders, all male, elected their class representatives to Tonga's legislative assembly, did this impede the political system from democratic reform? This last essay in a series of four dialogues with Sefita Hao'uli, Kalafi Moala, and Melino Maka prods a recurring sore in the side of democratic politics and liberal notions that all citizens are created equal by modern constitutional arrangements. How can these principles be practiced under a parliamentary structure that starkly exhibits partiality towards noblemen over and above commoners?

Teena Brown Pulu has a PhD in anthropology from the University of Waikato. She is a senior lecturer in Pacific development at AUT University. Her first book was published in 2011, Shoot the Messenger: The report on the Nuku'alofa reconstruction project and why the Government of Tonga dumped it. 


\section{Liberal reform}

Kalafi Moala's thinking on democratic reform in Tonga had not altered since he published his first book in 2002, The Kingdom Strikes Back. He admitted this in conversation with Sefita Hao'uli, Melino Maka, and I while discussing contenders for parliamentary seats in Tonga's November 2014 election (Moala, 2014). It was the first week of the university semester in March. We were seated in Greenlane McCafe in Auckland. All I could think was that Kalafi sounded peculiarly like how he wrote twelve years ago. I had not heard that voice for over a decade. Back then, he spoke from his gut. The writer had courage.

Seen in Tonga as the opening hard-hitter who steered local journalism to a new destination of holding government accountable for lack of public transparency in decisionmaking processes, Kalafi Moala took up the role of society's conscience (Brown Pulu, 2012). In his heyday of the 1990s he printed criticism, speaking out fearlessly against a corrupt political system based on nepotism and class privilege. By acting on his principles and beliefs he influenced Tongan writers, critics, broadcasters, and community leaders to educate themselves about high-level politics and to publicly engage in social commentary.

The human will to witness a new government enter in 2014 which would legislate in favour of a fully elected parliament had sparked up Kalafi's irrepressible fighting spirit. It was the same strength of character that got him along with the editor for his newspaper Taimi O Tonga, Filokalafi 'Akau'ola, and veteran politician 'Akilisi Pohiva, locked up in a Tongan prison for twenty-six days. Pohiva got let out early for medical reasons. But Kalafi and Filokalafi served nearly a month behind bars in the high-security wing of Huatolitoli, the national gaol. The year was 1996 when the Tonga legislative assembly sentenced him and his newspaper editor to thirty- 
days in jail for publishing an item about the impeachment of a cabinet minister; contempt of parliament was the charge (International Federation of Journalists, 1996). Pohiva went down with them for leaking the impeachment document as a people's representative.

The transformational aspect of Kalafi's jail time was that he single-handedly held the state culpable in the Supreme Court of Tonga, winning his 1996 case against the government for wrongful imprisonment. David slew Goliath. Here was the precedent for constitutional freedom of speech guaranteed to all citizens, commoners, noblemen, and royalty alike, which fuelled a political rationale. The Tongan state needed to democratise, modernise, and metamorphose into a national institution that shifted out of the 19th century to work suitably in contemporary times (Moala, 2002). Collective values and expectations of ordinary Tongan people had changed, but the state and social hierarchy underpinning its power base of top-down rule had not, and was not willing to find the middle ground. A fear prevailed that power-sharing with the masses would incur a loss of authority and the right to dominate (Lewis, 2011).

The late Futa Helu wrote the foreword for Kalafi's first book insisting that the final chapter "should be written in gold" (Helu cited in Moala, 2002, p. 10). It was his change politics that Futa took to. On this note, Kalafi was frank and forthright about the structural change he envisaged for Tongan state and society. Tonga's nobles were the focus of his critique.

Putting it bluntly, nobles are useless and should join the ranks of everyone else ... their social and political function is completely irrelevant. Unanswered questions to my mind have been: "What do the nobles do?" and "What roles do nobles play in Tongan society?" I admit the answers presented to me so far 
do not give them any relevant or useful role for the development of Tongan people. They are more often "pests" and at best, social burdens on the people. (Moala, 2002, p. 296).

Without a doubt, Futa's 'Atenisi Institute which he founded on an ethical practice to provide critical education to Tonga's underclass, that is, to students whose families could not afford to pay for an overseas university education, had grown social awareness about democratic ideals embedded in social equality. Futa himself had raised a generation on 'Atenisi scholarship that was pro-democracy and pro-critical thinking. In the closing sentiments of Kalafi's The Kingdom Strikes Back he was staunch that "the nobles are useless," a social class with an obsolete political function who were honestly "burdens on the people" (Moala, 2002, p. 296). Parliamentary structural reform inevitably involved abolishing the nine nobles' representative seats. If individual nobles intended to run for parliament they could do so under a general electoral system where they contested constituency seats like "everyone else" (Moala, 2002, p. 296). What was wrong with that?

For a start it was definitely not a model of democratic reform the monarchy and nobility would assent to, even today. In a coconut shell what made the ruling class exactly that, was they were the landed gentry by law, the estate-holders. As the minority group of men who controlled the majority of Tonga's land, their function was to lease out allotments to people congregating in their villages along with tenancy agreements to commercial businesses. A noble's political orientation in parliament was singular. Based on preserving their land entitlement which they inherited by birth right, this insular self-interested focus sanctioned a handful of men to maintain an elite minority rule over the majority population of commoners. But more than that, land holdings were a 
fundamental source of economy, power, and status by the mere fact of generating cash income.

\section{The nobility on reform}

During the 1990s Soviet Union dissolution of the Yeltsin presidency, Russian oligarch Mikhail Khordorkovsky emerged as his country's richest man and the world's wealthiest under 40 years old. Under the Putin presidency, the Russian Federation accused and tried Khordorkovsky for fraud, tax evasion, theft, embezzlement, and money laundering. He served ten years in a Siberian prison. In a media interview Khordorkovsky made reference to "the Singapore model" as the system by which the Russian state operated. Generally, he thought citizens recognised their government and country as a quasi-democracy in the sense that it appeared democratic on constitutional record but not by actual practice.

It is the Singapore model, it is a term that people understand in Russia these days. It means that theoretically you have a free press, but in practice there is self-censorship. Theoretically you have courts; in practice the courts adopt decisions dictated from above. Theoretically there are civil rights enshrined in the constitution; in practice you are not able to exercise some of these rights. (Mikhail Khordorkousky cited in Werbowski, 2010).

The likening of the Russian Federation to "the Singapore model" has been raised here for two interrelated reasons that resonate in the case of Tonga's democratic restructuring. From the outset Khordorkovsky signalled state institutions do not straightway become democratic by rewriting a country's constitutional arrangement. For the most part, a new national ideology shaping different political behaviour to past practices 
is adopted by the state, which subsequently determines how democratic in procedure the country really is.

Tonga, similar to late democracies that came out of the Eastern bloc's breakup under the Union of Soviet Socialist Republics (USSR), showed symptoms of a fledgling, fragile, failing state. Foremost, the economy travelled a downward spiral of instability. Consequently, the country's financial demise had exacerbated the adversarial scheming of a democratic opposition and a conservative government. To reiterate, the cut-throat and irreconcilable politicking of reformers versus conformers fired up uncertainty and distrust throughout the homeland state of 104,941 people plus its New Zealand, Australian, and American diaspora which was larger in number than the population living in Tonga.

The perceived danger with the 2010 parliamentary restructuring which enabled seventeen people's representatives to outnumber nine nobles was this; the nobility interpreted the systematic change as a potential destabiliser to their power and resource base - land. To neutralise the risk that at the 2010 election nobles might not be included in cabinet to protect their land benefits which were essentially business interests, Lord Fakafanua brought a private member's bill into the legislature. The bill aimed to extinguish cabinet's function to approve leases and tenancy agreements on nobles' estates granted by the Minister for Lands, giving the legal responsibility of accepting the minister's land agreements to the estate holders themselves. This provided Tonga's nobility with measures of land, asset, and wealth security. Above all, the proposal limited cabinet to land occupancy consents on crown holdings belonging to the state, leaving authorisations about the nobles' estates in their own hands.

Fakafanua's bill was palmed off to the Tonga Royal Land Commission set up by the late King George Tupou V to gauge 
public views on the current state of land ownership. This presented a softer option to the possibility of igniting a parliamentary fracas between nobles and people's representatives over a bill granting the nobility greater authority on land decisions. Given tensions were high in anticipation of finalising revisions to the legislative assembly's composition, the land commission dealt with the nobles' petition.

A proposed Bill to amend the Land Act was submitted to the Legislative Assembly by some Nobles in 2010. The most significant part of this Bill was to transfer the powers for approval of leases from Cabinet, and the power to grant land from the Minister of Lands, to the Hereditary Estate Holder where in involves land on his estate. The Bill was referred to the Commission by the Legislative Assembly of Tonga. It was included in the matters referred for discussions at meetings with the public who expressed their views, mostly not supporting the proposed Bill. The Bill was also discussed with Noble Estate Holders. (Tonga Royal Land Commission, 2012, pp. 6-7).

A rupture existed between what the noble class with reserved seats in parliament wanted political reform to deliver them, compared to the ideals of democracy enthusiasts craving transformational change to parliament and government. Why would any noble back democracy, given they stood to lose social standing and financial primacy gained from estate holdings as the country's traditional rulers? Furthermore, whose responsibility was reform? Historical accounts of Tonga argued political reformation and social change since the investiture of the 19th century King George Tupou I had always been executed by the Tupou monarchy 
from the top-down, not by the people from below, the commoners.

Without a doubt, 2010 was the year that marked constitutional change in expectancy of how a new government would be formed. Under the former Prime Minister Feleti Sevele's administration, amendments to legislation allowed for an increase from nine to seventeen people's representatives elected by registered voters on the general roll. As well, a parliamentary vote for the premier would take place, and in turn, the elected prime minister would appoint cabinet ministers rather than the presiding monarch.

While the Tongan public assumed that a commoner government would rise to power because finally there were more of us than them in the legislative assembly, a compromise was cut. Tonga's nobles and estate holders grudgingly agreed to parliamentary adjustments on one condition. The minister for lands was to be an exclusive appointment reserved solely for one of the nine noble's representatives. It was this prize, a noble minister as the state authority governing over lands, which forestalled land reform from featuring highly on the common people's wish list for change, let alone getting anywhere near the country's lawmakers in the legislature.

The speaker of parliament was the second role earmarked for a noble's representative. This was not to be downplayed. Holding on to the roles of minister for lands and the legislature's speaker allowed the nobility to manoeuver their political will in parliament and government unobstructed, for the simple reason that the people's representatives could not legitimately contest, or in any way occupy, either appointments.

In November 2010 after registered voters and the nobles held their separate elections which was during the lead-up to Lord Tu'ivakano winning the prime minister's election in 
parliament, Lord Ma'afu gestured to media that land signified the nobles' policies and priorities. As expected Tu'ivakano appointed Ma'afu his minister for lands not simply because they were nobles of the same clan Ha'a Havea Lahi, but more so, Ma'afu's politics were fundamentally traditional. By this, he demonstrated an anti-reform ideology which opposed the liberalisation of Tongan land law to loosen the tight-fisted control of the monarchy and nobility.

The priorities for nobles in the upcoming government will include land issues, reviving the economy, and unity amongst members of the House. (Lord Ma'afu cited in Latu, 2010b).

It could be said that the royal land commission's 2012 proposal which in theory (but not reality) aspired to restructure Tonga's land tenure and management system had no effect because Ma'afu was the minister for lands. He was "the representative of the Crown in all matters concerning the land of the Kingdom" (Tonga Land Act, 1988, p. 16) who held the power to recommend or deter the Tonga Royal Land Commission Report (2012) from proceeding to cabinet. Principally, the minister was instrumental in deciding whether the land commission's ideas were reviewed by the national executive or not.

"Despite the fact that twice during 2013, there were motions for it to be debated in the house," wrote Kalafi Moala, the land report vanished from parliament's radar and for no intents or purposes was it mentioned by the government (Moala, 2014a). Frankly, not one press statement from the prime minister's office or the ministry of lands notified Tongan people the report had been officially submitted to the late monarch, and that a PDF version could be downloaded from the internet for public reading. On reflection that the commission's operation and producing the actual report cost 
the state over TOP $\$ 3$ million Tongan dollars, the contention that it was in taxpayers' interests for parliament and cabinet to hash out its contents made value-for-money sense (Moala, 2014a).

On arguing this point, Kalafi Moala cited 'Akilisi Pohiva in a political commentary published by the Pacific Institute of Public Policy in Port Vila, Vanuatu. Pohiva added that while the land commission report never got on the legislature's schedule, Tonga's noblemen were busy "trying to amend land laws to" strengthen preferential treatment for themselves (Moala, 2014a).

To this day, the report and all the recommendations it made still has not been presented to Parliament. In the meantime, the nobles who are the large estate holders are already trying to amend land laws to make it favourable to them. ('Akilisi Pohiva cited in Moala, 2014a).

Four years after Tu'ivakano's inauguration as prime minister was the end of the road for this noble premier and his hand-picked cabinet ministers. But the government's 2010 to 2014 term had amplified the call for a people's movement to become more pressing than ever. When it came to lusting after land because there was cash to be made from leases, why would ordinary people have confidence that title and estate holders would impartially govern the country? Kalafi Moala pulled no punches. Tonga's problem was that the Land Act (1988) specified up to five per cent of a noble's estate could be leased to businesses.

In real life there were nobles with commercial leases over the limit, collecting land revenue valued in "millions of dollars" (Moala, 2014a). This contentious situation stirred a second criticism that Kalafi drew from nobles being the sole recipients of rent that came off public infrastructure, buildings, and 
areas, such as "airports, [hospitals], wharfs, power stations and schools" (Moala, 2014a). Why did the lease revenue not get diverted back into the provision of state "services that benefit the citizens of Tonga?" (Moala, 2014a).

The critical issue facing Tonga is that while nobles are leasing out large quantities of their land for millions of dollars, there are a lot of their people who are without land. (Moala, 2014a).

A point that reformers are starting to debate openly is money generated from leases for publicly used land such as the airport, the wharves, power stations, and schools should go to public services that benefit the citizens of Tonga, rather than to estate-holders. (Moala, 2014a).

Preceding the general election, community leaders Sefita Hao'uli and Kalafi Moala who were established journalists, and Melino Maka, himself the chair of the Tongan Advisory Council in Auckland, asserted that history from below, change driven by the ordinary people, mattered. By their decree, a national reform programme wanting to sustain itself for the majority of Tongan people had to reverse top-down governance and embed change management from the bottom-up (Bond, 2006; Hoff, 2003). But the question was how; that is, by what methods and communication strategies? Importantly, who were the genuine leaders of a people's reform that if elected to power would not sell out the very people from below who had voted them in?

The excerpt below is from a conversation with Sefita Hao'uli, Kalafi Moala, Melino Maka, and myself in Auckland, New Zealand, on the morning of March 6th 2014. Threaded in between sections of this essay are selections from our development dialogue. This fourth and final article we co- 
constructed as colleagues, correspondents, and critics was the most serious of our talks with the least amount of jesting.

From conversing across a host of development topics located in Tonga, I came to know the banter and repartee exchanges of Sefita, Kalafi, and Melino as a Tongan male communication strategy for using humour to point criticism. I can only guess that this particular discussion was conducted in a more solemn tone than previous meetings because the subject of who owns Tonga and interrogating what had gone amiss was worrisome, irksome, and emotionally taxing.

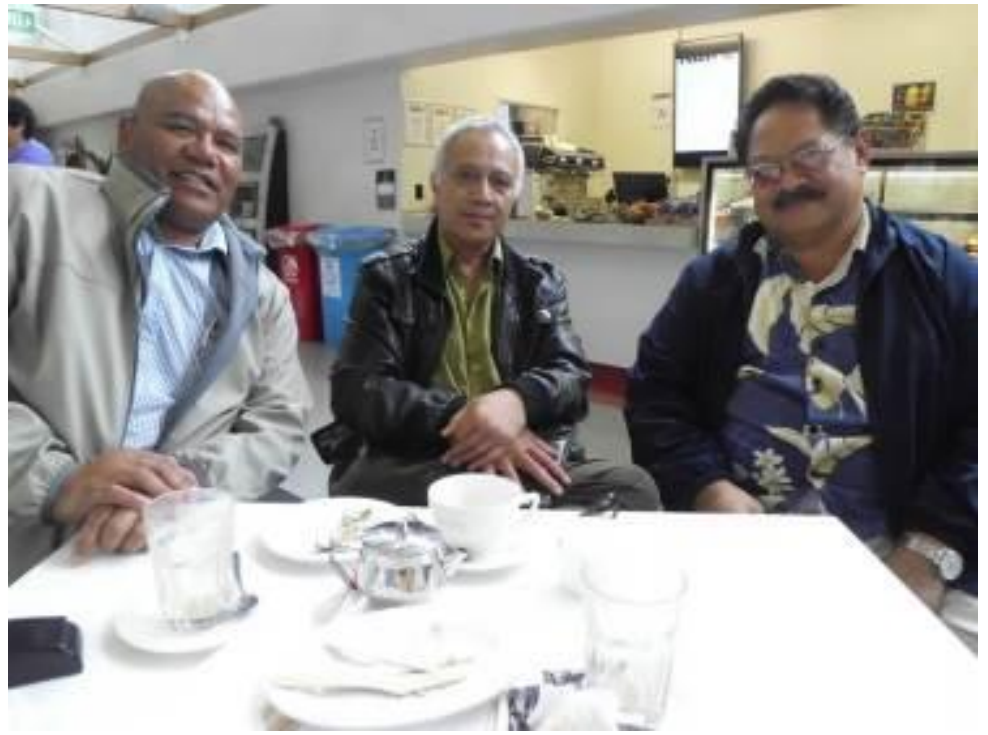

Melino Maka, Sefita Hao'uli and Kalafi Moala at the South campus, Auckland University of Technology in the New Zealand spring of 2013.

In all self-centred privilege, which middle-class academics and writers have been known to exude without realising they symbolise a preferential class group in any given society, I was saddened to bring the development dialogues to a close. I had 
gained immeasurable knowledge about myself, my biases, my insecurities, my limits to understanding Tonga, and my strengths in what I could offer to the country's progress from talking to these older generation men; all born in Tonga and loyal to their roots, people, place of belonging, and ideals. They challenged me to think outside of my comfort zone and empathise with Tongans in the homeland who had very different lives from my own. For that valuable experience alone - human empathy - I felt humbled and grateful.

\section{A short play: Scene 1: Bottom-up reform}

Sefita Hao'uli: Our job is to further reform the political system. Every man and woman's political act is to continue the continuum. The people shape the political agenda. But how it is done, the method by which reform is carried out, has a significant impact on the country's future.

Melino Maka: Change will come in 2018. This election in 2014 will set up political players and the country's move towards reform that will come at the 2018 election. You can't stop change. The leaders have to learn how to make change beneficial for Tonga, for everyone, not just go into politics for themselves. There are too many people there already who are helping themselves and don't worry about the country, and that's on both sides, the nobles and the people's reps [representatives].

SefitaHao'uli: 'Akilisi [Pohiva] is Tonga's most influential politician ever to hold power but be uncorrupted by it. When people ask me what has he done in politics, I say that without 'Akilisi's twenty eight year contribution to political life, Tonga would not have changed thus far towards a general acceptance that a democratic arrangement of power is the most relevant way to govern the country.

Kalafi Moala: There is still a political mind-set in Tonga defined by age groups where young people say no, 
government and politics do not affect my life and I don't care who's in government because this doesn't help me get a job, pay bills, and better my life. The middle-aged and older men are the group wanting to influence the country through politics and getting into parliament. They look at being a people's representative as the way to have influence at national level, positive change, or what they think is positive for the country.

Sefita Hao'uli: The reform process has to come from the bottom-up. Modern world history shows us that liberals have always won battles for change, battles for the people; conservatives have never won a battle. There has to be a planned and systematic way to speed it up, the process for reform. We can't see it falter on the side of what is likely to happen, which is quite simply a democratic parliament where all members are elected by the public. What I want to see is a government with a twenty year vision for Tonga that has five to ten year breakpoints for reviewing how the outcomes of a twenty year national plan are being achieved.

Kalafi Moala: I have to tell you what I've been thinking about and working on, and maybe you won't want to be friends with me anymore. I've decided to support 'Akilisi [Pohiva] in the election. Some people don't want to talk to me now, but there are a lot of people who say, good on you Kalafi, and they agree with me. They say it quietly. In Tonga it's the common people, the poor who are 'Akilisi's support base. But the public servants and the business people, they might endorse him but they don't say it loudly. It's possible to lose friends because of who you are supporting in the election.

Teena Brown Pulu: I don't have a problem with that. How does this essay weave together? If we go that way with development theory, if we write left criticism, we'll get no backing from the nobility and the business sector who run Tonga. Kalafi, now you're like Sef [Sefita Hao'uli]. You'll have no allies in Tonga with power and wealth for publicly stating 
you support 'Akilisi [Pohiva]. All you have to rely on is yourself and your will to stay true to your principles. Loyalty to people at the bottom will get you in trouble with the hierarchy. (Brown Pulu, 2014a).

\section{Land and women}

On March 30th 2012, the Tonga Royal Land Commission Report was submitted to the late monarch by the chairman who is also now deceased, Baron Fielakepa. An account taking almost four years to complete, the commission was "established by His Majesty, King George Tupou V on 9 October 2008 and confirmed by the King in Privy Council on 10 October 2008 to [appoint] Commissioners to inquire into any matter in which an inquiry would in his opinion be for the public welfare" (Tonga Royal Land Commission, 2012, p. 19). This was the second commission to publicly review Tonga's land tenure system, the first occurring almost thirty years ago in 1983. The 2008 group comprised of a chairman and three commissioners, one of whom resigned, and a secretary. In the end it was Baron Fielakepa, Tevita Tupou, and Kahugnugu Baron-Afeaki who signed off on the final version with Gloria Pole'o who is now the chief clerk of parliament in the job of secretary.

The report detailed over 120 recommendations; 99 of these decided by the commissioners themselves based on public meetings, and 21 put forward by the nobility, the constitutional estate holders of the greater part of Tonga's landmass. The overarching purpose of the recommendations was to detail public opinion on improvements to land tenure and management. Expressly, a political interest predominated. The authors sought to amend sections of the Tonga Land Act (1988) allowing for an "independent land commission" to take over from cabinet in approving land leases and allotments (Tonga Royal Land Commission, 2012). 
In effect, the not-so-independent land commission would act as an advisory body to the Minister for Lands who by an amendment to Tongan law in 2010 could only be a nobles' representative to parliament. Fundamentally under the Tonga Land Act (1988) the noble minister was tasked with the state responsibility of granting leases. Additionally an "independent land commission" to counsel the minister and a "land tribunal" to rule on public complaints were to be inaugurated (Tonga Royal Land Commission, 2012). Truthfully, how classless and democratic in principle was the planned set-up? Considering the land commissioners appointed by George Tupou V were three lawyers and members of the King's Privy Council, where one was a noble and estate holder and another had life-peerage and a lord's title, how impartial and nonpartisan were these advice-giving men making suggestions for change?

Indeed the royal land commission coveted structural change but it clashed with a complete remodelling of political power, the kind that Kalafi Moala had advocated. Without beating around the bush, Kalafi wanted to put an end to the nine special seats set aside for nobles in parliament. Contrastingly, an "independent land commission" advising a noble minister for Lands, and consequently removing the role of cabinet to commend leases and allotments, courted the nobility's desire to intemperately control their estate holdings. Where was the check and balance on the nobility's power? (Tonga Royal Land Commission, 2012).

Noted in the report was a proposition for the "Minister of Lands post" to be openly contested and filled by "the person most suitable," which did not entail restricting the position to "a Noble of the realm" (Tonga Royal Land Commission, 2012, p. 273). 
That the Minister of Lands should be the person most suitable for the post but not need be a Noble of the realm. If a Noble, then decisions concerning his estate will be made by the independent Land Commission. (Tonga Royal Land Commission, 2012, p. 273).

Driven by a public outcry against constraining the minister's job to the nobility which was expressed at consultation forums held in Tonga, New Zealand, Australia, and America, this recommendation was a concession. In exchange for backing popular opinion among the commoner class, the report's authors proposed that a land commission was the ideal replacement organisation to seize cabinet's role.

Under the present structure, which ironically was said to be modified, the landed gentry continued to subjugate the commoners. They retained their special seats. They held a separate election from the commoners. And importantly, they kept the minister for lands appointment within the jurisdiction of the ruling class. The minister for lands was a strategic position that gave them muscle. To recap this, Tongan law specified the minister's post was exclusively for a noble not a commoner member of parliament. This was purposeful. As a class faction, the nobles presumed a minister who was one of their own would loyally govern in their financial interests. Collectively, estates were the economic powerbase sustaining the political might of the status quo.

How did further democratisation and the separation of power figure in this governance arrangement? The short answer was plainly it did not: end of story. Outwardly structural modification may have been proposed through a land commission succeeding cabinet by advising the minister on decisions about the transfer of land, leases, or rental contracts. However, this adjustment held the likelihood of increasing the minister for lands' state power as the sole 
signatory authorising the legitimacy of land agreements. Had the Tonga Land Commission Report (2012) wedged open a new chapter on power and land disparities?

Sefita Hao'uli argued it was in the country's interests to "sort out" land matters by publicly inclusive and transparent forums, as opposed to sanctioning these discussions for nobles to conduct "behind closed doors." It defeated the purpose of democratising the state if "the land issue [was left] untouched" to avoid any risk that the ruling class might become irate with common people scrutinising the land tenure system (Hao'uli, 2014).

Remarking that the "Commission's report" could have gone further to give a detailed picture of Tonga's land situation, rather than purely highlight the commissioners' wish list, Sefita hinted that public consensus on what the "role for the nobles is" had to be pursued (Hao'uli, 2014). Without disseminating correct information to the public, inviting debate, developing general agreement on what the conflicts were, and gaining endorsement for a system that managed discrepancy, how could land matters be adeptly resolved? Where the royal land commission went astray was that they jumped the gun. Pushing their own wagon for an "independent land commission" to replace cabinet, the commissioners did not put this to the public first to gauge whether it was what people wanted, and if popular opinion saw it as a fairer process than the present one.

Like it or not, the longer we leave the land issue untouched, the more likely it is to come up and bite everyone in the proverbial later. Land tenure and the nobles' role in the "ownership" and distribution of land is not just a nobles' issue to sort out behind closed doors. It is in everyone's interest that this issue is fully debated in public. But an informed debate will only be possible when all the facts surrounding land are 
known. The Commission's report has some but not nearly enough to enable the landowners and the landless to appreciate what is ahead of us. The "custodian" role for the nobles is interesting and will need to be properly contextualised constitutionally and historically so that we can arrive at an agreed definition of "custodian." (Hao'uli, 2014).

Glaringly there were social groups the report downplayed in relation to gaining fair and equitable access to land. In a Facebook conversation, the director of Tonga's Women and Children Crisis Centre, 'Ofa Guttenbeil-Likiliki, explicitly spelled out that women did not receive equal entitlement "to own land" as their male counterparts. My response was aghast at the "misguided assumption" of the male report writers in deciding that Tongan women did not require cultivation land because only men farmed for subsistence and commercial income. This was not true, nor was it a fair and judicious rationale on which to make a commissioned recommendation.

'Ofa Guttenbeil: Only one written recommendation for women to own land. Outcome: recommendation for women to be able to register a town allotment but not a bush allotment because obviously as one of the commissioner's so blatantly put it, "only men do agricultural work."

Teena Brown Pulu: What a misguided assumption, 'Ofa. I feel like inviting the former commissioner to Kolonga to meet my dad's sisters/female cousins. My Kolonga grandmother was a farmer and goodness knows how many generations of women have been horticulturalists and primary income-earners in Tonga. (Brown Pulu, 2014a).

On February 14th 2014 King Tupou VI's wife, Queen Nanasipa'u, gave a telling address as the chairperson of the 
ex-students committee for Queen Salote College. Broadcasted on Radio and Television Tonga, Nanasipa'u delivered an appraisal of women in Tongan society emphasising that "we are fortunate that women are allowed to lease their own land." Whether this was indisputable truth for all Tongan women was not the Queen's discussion topic. She was speaking in polite layers of courtly counsel, directing her women subjects to take heed of the advice.

There were two urgings Nanasipa'u put out in the public domain. Firstly, women should use any opportunity afforded to them to "lease land for commercial reasons." Secondly, "to have a female representative in parliament to express our opinions" is integral for women to have influence at the level of national "decision making" (Television Tonga, 2014a). Precisely which commercial industries she intended women to develop by acquiring property, and what banks in Tonga financed start-up businesses for women, the present King's spouse did not detail. As for electing a woman to parliament, the speech inferred that preventing male "domestic violence [against] women and children" was suited for female advocacy in the legislature (Television Tonga, 2014a).

"There are opportunities given to women. All over the world, women have access to different opportunities such as education. Some have education and some don't. In Tonga, we are fortunate that women are allowed to lease their own land. For example, widows are allowed to lease land for development reasons. Sometimes women don't recognise good opportunities when it's given to them like leasing a property. They will give it to their partner or the men. But women can also use that opportunity and develop it for commercial reasons or other reasons which will help them financially. This is not a local concern. It is common in the Pacific and everywhere in the world. People's voices are heard in parliament. We need to use 
that opportunity and make sure women's voices are also heard in parliament and women are engaged in such decision making. It's crucial for us to have a female representative in parliament to express our opinions." [The] other issue raised by Her Majesty is concern over women and children who suffer from domestic violence and the need to protect them from such actions. (Queen Nanasipa'u cited in Television Tonga, 2014a).

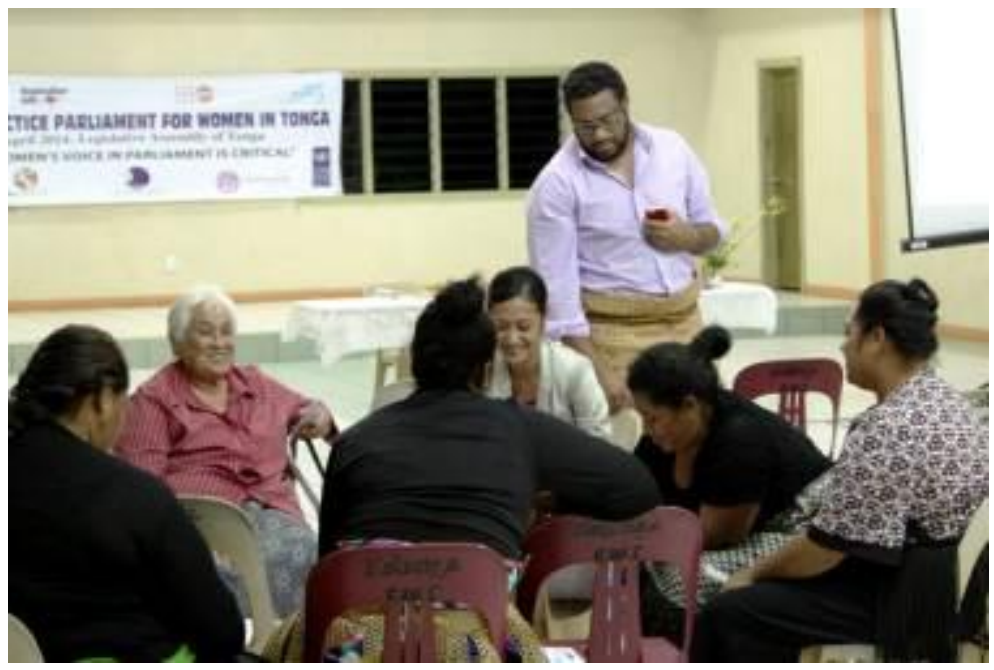

Speaker of the legislative assembly, Lord Fakafanua, stands over women from Kolonga village at a workshop designed to recruit participants to the practice parliament for women in Tonga. (Photograph by Practice Parliament for Women in Tonga, 2014).

Nanasipa'au's key messages that women must utilise land for commercial advantage and mobilise to vote one woman into parliament were not surprising. Increasing the numbers of women in paid employment and parliament were widely held notions promoted in developing countries by the United Nations Development Programme, the Pacific Islands Forum, 
and the Western aid donors of Australia and New Zealand. Compliantly the Tongan state, non-government organisations, and churches backed women's development projects largely because the government was expected by international donors to devise national policy aimed at improving women's lot: aid funding depended on it.

Conspicuously there was political inconsistency in the Tongan parliament and government made up of men, with the exception of one women Dr 'Ana Taufe'ulungaki who was appointed to cabinet by the Prime Minister Lord Tu'ivakano and not elected to parliament. They had stalled on ratifying the United Nations Convention on the Elimination of All Forms of Discrimination Against Women (United Nations Human Rights, 2014; Government of Tonga, 2014). Their stand was carried over from the former Prime Minister Feleti Sevele's term where he stated at the United Nations General Assembly on September 26th 2009 that Tonga's legislative assembly would not ratify the convention because "certain provisions go against Tongan social and cultural tradition" (Thomson, 2009). Explicitly, the Tongan parliament objected to amending "national laws regarding land and inheritance rights, abortion, and family planning" (Thomson, 2009).

Sevele's United Nations address avowed that "Tonga would rather be judged on its actions of empowerment of women in Tongan society over the past century than by a ratification of convenience" (Thomson, 2009). It was a judgement that the Tu'ivakano government obediently upheld, framing public policy on gender equality by a romanticised notion "that women are cherished and respected in Tonga without the convention" (Thomson, 2009). A form of cultural brainwashing contrived by patriarchy and paternalism, the fact women reported male violence against them as a social norm in a 2012 national study funded by the Australian government disputed any absolute truth "that women are 
cherished and respected in Tonga" (Thomson, 2009; Jansen et al, 2012).

At a September 2011 meeting with the United Nations Secretary General Ban Ki Moon in New Zealand, Tonga's Prime Minister Lord Tu'ivakano maintained the official line that "the integrity of women in Tonga is of high standing both in its cultural and social aspect" (Government of Tonga, 2011). Perceptibly the Tongan "cultural and social" argument wore thin when it came to women gaining equal rights with their male counterparts to inherit or lease land. Tu'ivakano's reasoning about "hindrances" preventing structural change to Tongan legislation enabling women to acquire land was painted in oblique language.

Quite clearly his government deferred from taking action on land inequalities. It would "require time if Tonga" were to amend the Land Act (1988) and parliament were to approve the United Nations convention, said the prime minister. If was the operative word, which in plain English meant it was uncertain if thy Kingdom come, thy will be done on earth (a pun on the Lord's Prayer intended).

However, there are several hindrances in the legal and constitutional structure of Tonga and will require time for adjustment if need be. This included land ownership and inheritance which required clear and concise guidelines if Tonga was to ratify CEDAW (United Nations Convention on the Elimination of All Forms of Discrimination Against Women). (Government of Tonga, 2011).

Former Prime Minister Feleti Sevele's declaration that "Tonga would rather be judged on its actions of empowerment of women in Tongan society over the past century than by a ratification of convenience" remained the fixed position (Thomson, 2009). Queen Nanasipa'u's brother, Lord Vaea, 
was the Minister for Internal Affairs in the current Tu'ivakano government. In March 2014 at the United Nations 58th Commission on the Status of Women, Vaea asserted that "Our Government has recently adopted several measures to reduce gender inequality, improve women's livelihoods, protect them from domestic violence and improve their economic empowerment" (Government of Tonga, 2014). Specifically, the minister was gesturing to the 2013 family protection bill which he brought into the House and was passed into law.

In that statement the Hon. Minister [Vaea] had brought the Commission's attention to his Ministry's prioritization of tabling the Family Protection Bill which would provide and ensure key protection and access rights for victims of domestic and family violence. (Government of Tonga, 2014).

A visible alignment could be traced to Queen Nanasipa'u's verdict that Tongan women were lucky because Tongan men have permitted them "to lease their own land," and Lord Vaea's assurance that his government of eleven men and one woman was lowering "gender inequality" (Television Tonga, 2014a; Government of Tonga, 2014). Read in this context, the discussion of siblings belonging to Tonga's ruling class, by no means were their insights value-free, but instead, a public conveyance of highly politicised sentiments geared towards sustaining the status quo.

Nanasipa'u and Vaea cautiously put off bringing up the Tonga Royal Land Commission Report (2012) making no allusion to land reforms benefitting women. From the landed gentry's standpoint, what was the status quo obsessively guarded about? Moreover, from whom were they protecting themselves and their interests?

On August 6th 2010 the solicitor general of Tonga crown law office, 'Aminiasi Kefu, wrote to Lord Fakafanua, a noble's 
representative, offering legal advice. Kefu's correspondence was about strengthening the nobility's position of advantage to operate in a parliamentary setting that had more commoners' seats in the legislature than nobles.

The land governance issue arises from the political reform process creating an elected Cabinet by the people and the Nobles, rather than appointed Cabinet by the King. The Cabinet is the main authority to approve land matters. The concern is that an elected Cabinet may not have the interests of the nobles in mind given the possibility there may be no noble in Cabinet or a noble may not be the new Minister for Lands.

There are three options available:

(1) Option A: Retain the status quo;

(2) Option B: Assign authority to Estate Holders; or,

(3) Option C: Establish an independent lands titles authority. (Kefu, 2010, pp. 1-2).

From Kefu's list of "options available" the nobility merged $\mathrm{A}$ and $\mathrm{B}$ and vied for this two-fold combination. Foremost, to "retain the status quo" was realised by amending Tongan law ensuring the minister for lands' appointment went to a noble parliamentarian (Kefu, 2010, p. 2). Subsequently, to "assign authority to Estate Holders" was the land reform strategy underpinning the bill that Lord Fakafanua took to the legislature in 2010 (Kefu, 2010, p. 2). When the bill's contents were turned over to the land commission to deal with in their TOP \$3 million pa'anga report, the nobles prioritised having authority over their landed estates in the 21 recommendations they put forward. As for "Option C," the land commissioners made this their own agenda by plugging for "an independent lands titles authority" (Kefu, 2010, p. 2).

After carving up the land authority pie between the nobility and the land commission, it was detectible that 
talking up women in parliament was a diversion tactic. Tonga's crucial development issue was land tenure, which the nine nobles' representatives in parliament alongside the noble premier and his two noble cabinet ministers hid from public consideration, but consulted about in private. For the nobility, Tonga's ruling class of male title and estate holders, why was increasing women's representation in the legislative assembly of political use to them?

Kalafi Moala cited 'Akilisi Pohiva's deduction: "Pohiva believes this move, which is most unlikely to be accepted, is simply an attempt to justify the nobles retaining their own assigned seats" (Moala, 2014b). Although Pohiva thought that the nobility had gone as far as supporting a quota system that reserved special seats for women in parliament, this was definitely not the stance of Lord Fakafanua, the noble speaker of the house.

I don't support legislation in place that would convince voters to vote for a 10 percent reserved seats for women. This is not looking down on men but there's a need for male and female to collaborate more to let women's voices be heard. When there is legislation for a quota system, it is tripping off voters' constitutional [right] to vote. (Lord Fakafanua cited in Parliament of Tonga, 2014).

I am not aware of why women did not claim any seats in parliament. I think this is a social issue. I don't support drafting a bill to have special seats for women because it will limit human rights to become a candidate for parliament. What we are trying to do is motivate women because they will help a lot in shaping governments obtain good governance and gender equality. However, Tonga Legislative Assembly maintains a parliament that is in line with the present needs of the people 
and to equally represent its people. (Lord Fakafanua cited in Television Tonga, 2014b).

As the speaker of the legislative assembly, Fakafanua was inflexible about his contrary opinion on women in parliament. He did not "support legislation" allowing parliament to allocate "10 percent reserved seats for women" (Parliament of Tonga, 2014). On the other hand, he endorsed the legislature having 35 percent of its seats represent a minority group of 33 nobles and estate holders who were men in a country of 104, 941 people. To stamp a highhanded tone of unfairness and inequity on his political view, Fakafanua approved of the legislature comprising of 35 percent nobles' seats in which the nobles were not elected by Tongan citizens registered to vote in the general election. He expressed the attitude of Tonga's nobility. The difficulty was how did this contradictory stand amount to pragmatic support for boosting the membership of women in parliament?

In Fakafanua's mind, "no institutional barrier to women entering Tonga's parliament" existed (Haas, 2014a). But with all patriarchal, top-down, self-important judgements, he made an estimation based on his own reality in which "there is no institutional barrier to [nobles] entering Tonga's parliament." Undoubtedly the rules that Fakafanua lived by did not apply to Tongans not of the noble class. Laws and canons which safeguarded his privileged position in society and the economy as an estate holder were not applicable to commoner women. The culture of everyday life revealed that ordinary Tongan women constituted the group most discriminated against by the Tongan state and society; women were the group deliberately legislated out of equal land entitlement and parliamentary participation. 
Lord Fakafanua says there is no institutional barrier to women entering Tonga's parliament - yet in the 2010 general election no women were elected. Women can do it - they already occupy senior public service roles in Tonga he said at the beginning of Tonga's 2013 general election year. (Haas, 2014a).

For Fakafanua to flippantly remark that "women can do it," they can effortlessly get voted into parliament seeing "they already occupy senior public service" jobs, failed to recognise that structural inequality is a valid factor proscribing full access and participation. To claim it is merely "a social issue" isolates the absence of women in parliament from the context of institutional constraints that need amending to create parity for women (Haas, 2014a).

\section{A short play: Scene 2: Land is the election issue}

Sefita Hao'uli: Land is important to Tongan voters. The opposition party is expected to have clear leadership and policy on what the difficulties are, and how a new government will resolve the difficulties for the benefit of all Tongans. To spell out the difficulties, land holdings are up for grabs. The role of academia is to look closely at the sensitive area of land in a critical way that explains why the tensions exist and persist in Tonga. In theory, this would shed light on fair solutions. But it is an area that academia won't touch.

Teena Brown Pulu: I agree. Land is the most contentious issue in Tonga. Academics won't touch it. They fear the conflict it incites between the monarchy and nobles against the people. Self-preservation rules over being well principled and doing your job honestly. The educated middle-class are about appeasing the ruling class because the middle-class, especially half-cast families and foreigners dominating the business sector, get favoured over poor Tongans in the hierarchy. 
Melino Maka: Land of national interest has to be brought up to inform the people. The nobles, the amount of money Kalaniuvalu received from government for the airport lease at Fua'amotu. Rent made by the noble should go back to the government to keep the airport costs down for the public. The public should benefit from land of national interest, not the noble living in luxury.

Kalafi Moala: The Land Commission report; that should have information about this. This needs to be explained. The support for 'Akilisi [Pohiva] from the grass roots is really strong. But a lot of folks are misinformed and need to have the facts put before them. There are time constraints, seven months until the election, but we do need to publicly talk about land.

Sefita Hao'uli: $\quad$ Land has become a problematic area for Tongans. Tupou $V$ gathered opinion through the Land Commission report. People are scrambling for land but the point is, land is of no use to the nobles if nobody likes the nobles. If land can't be dealt with fairly by rules for the benefit of all then the nobles do not have a role. Effectively, they have made themselves redundant.

Teena Brown Pulu: Nobody likes the nobles because the Prime Minister [Lord Tu'ivakano] and his wife [Robyn Sanft], [Lord] Ma'afu and [Lord] Vaea are so very unpopular. People have labelled them the worst government ever. Ha'a Havea Lahi has lost political power because of Tu'ivakano's government. Leading Tongatapu now are the eastern district nobles, and for the outer islands it's [Lord] Fakafanua and the young nobles like Fulivai. The fact there are nobles' estates over the 5 per cent threshold of commercial leases granted to businesses must be accounted for. [Lord] Fakafanua is one. Tonga can't have nobles selling off more business leases than what they're allowed so they can make large amounts of money for themselves; while poor Tongans can't even get land to live on and grow vegetables to eat. 
Sefita Hao'uli: $\quad$ Put it before the public in a question: who owns Tonga?

Teena Brown Pulu: We do. The people. (Brown Pulu, 2014a).

\section{'Different expectations'}

In an interview with American anthropologist, Jeanette Mageo, the late noble Ma'afu who was the present Lord Ma'afu's father explained "the Tonga we have today" understands that structure - "the King, the nobility and the people - is the essence of our tradition and culture" (Mageo, 2001, p. 47).

It is my belief that the structure that he [King George Tupou I] formed is the corner stone of the Tonga that we have today. It was the corner stone that assured freedom for the people of Tonga. It was the corner stone of the work that ensured Tonga remained free of the Colonial designs of the governments of Europe. We are still free and proud of it. [The nobles] hold together the strands of the traditions and culture that we value in this country. The communion between the King, the nobility and the people, that is the essence of our tradition and culture. Yet the task that is called a burden is the very effort that holds Tongan culture together. (Noble Ma'afu cited in Mageo, 2001, p. 47).

Ma'afu was right in an authoritarian manner to presume how Tongans were conventionally socialised to grasp and practice national identity. "Structure [underpins] tradition and culture," which is why the nobility was fearful that if the parliamentary structure was reformed to do away with their special seats, what would become of Tongan "tradition and culture" in the running of government and the state? (Mageo, 2001, p. 47). 
Tonga's die-hard left of which 'Akilisi Pohiva was its progenitor took an uncompromising view: tradition and culture were to be separated out from a democratic government, a secular state, to operate solely in social not political life. This was easier said than done, and what became apparent during the Tu'ivakano administration which took office after the 2010 parliamentary reform was that the hierarchical "structure of tradition and culture" had not been collapsed, just tweaked for appearances (Mageo, 2001, p. 47).

Keeping up appearances was no longer a tactic that would sustain the nobility enduringly in politics. Noble ministers and parliamentarians got called out for their slackness in the public service. Ordinary Tongans slammed them for being unqualified for the job, invalid in thinking they were superior, unable to do the work, and unprofessional in the public domain.

Also rife was criticism against the people's representatives, both the Democratic Party opposition and the independent members of parliament. Publicly it looked as if their political dilemma was the failure to communicate a "long-term vision" for the country. Confined to "living from one election to the next," an effective opposition that held the government to account as well as independent politicians who did not come across like the nobles' flunkies, declined to appear on the political spectrum (Anonymous Informant 1, 2014).

The nobility has been given a chance to step into the breach created by political changes made possible through people's agitation and frustration over five decades. Under the Prime Minister's leadership, they've shown little inclination to implement changes to signal that we've entered into a new political age and that the people have different expectations of leaders in government. I sense that our new crop of politicians are living from one election to the next. Their behaviour tells us 
so because there is no long-term vision from any of them. The nobles are used to being served and they serve when they want to and to whom they feel obliged. Leading the country, on the other hand, is about serving the population as a whole and under the Prime Minister this public service isn't there. He has never been able to make it a new era in politics led and implemented by the nobility. He has turned it into a return to a darker age by appearing weak and indecisive. Worst of all, he's been distant, divisive, and bordering on the corrupt. (Anonymous Informant 1, 2014).

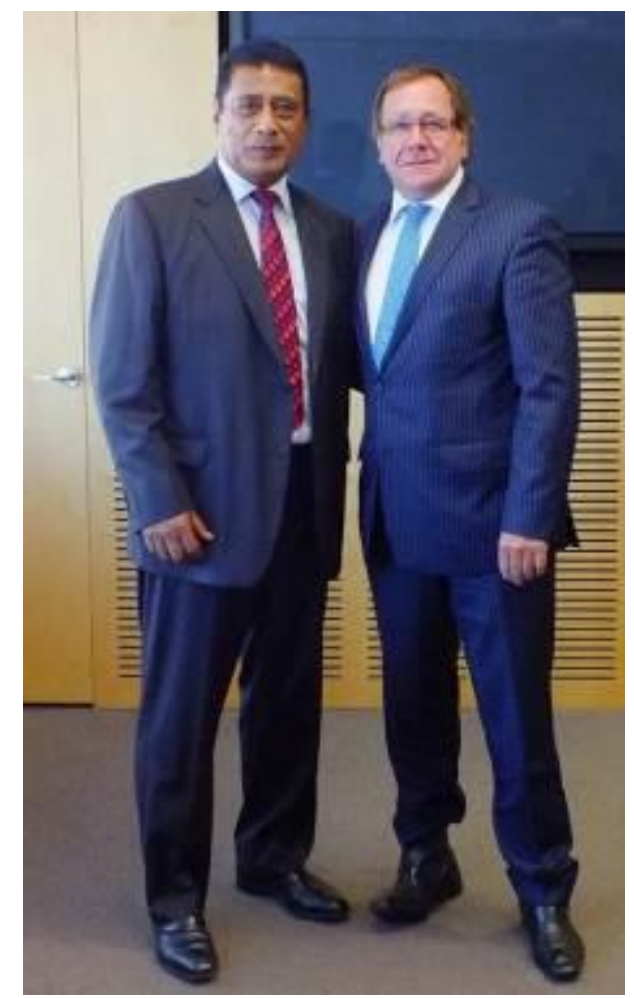

Prime Minister of Tonga, Lord Tu'ivakano, and New Zealand Minister for Foreign Affairs, Murray McCully at 


\section{Auckland in March 2014. (Photograph by Radio and Television Tonga).}

\section{A short play: Scene 3: Who will stand with the people?}

Kalafi Moala: I've been in Tonga for three months watching the political alliances between contenders for parliamentary seats and the parties being formed. There's a number of independent candidates contesting constituencies. There's the Conservative Party led by [the noble] Tuipelehake with his supporters such as 'Eseta Fusitu'a [the noble Fusitu'a's wife]. There's the nobles party with various nobles wanting the leadership.

Teena Brown Pulu: Self-preservation is the driver for the nobles bidding for power at this election. They need to preserve their political seats and financial power through land ownership. That's what ties this alliance together. In real life they are divided; in-house scrapping and rivalry is rife. It will never happen. We will not have another noble prime minister leading the government after the Tu'ivakano government ran the country down to completely broke and made life, money-wise, harder for everyone.

Sefita Hao'uli: But it could happen; they're still the most organised political party in Tonga.

Teena Brown Pulu: Not organised; they're an established group who've held on to power the longest by dominating government and land assets. The leadership is split and weak; no political principles and policy platform inclusive of all Tongan people and the country as a whole. Nobles talk about their estates, their land, their asset wealth, their power. They don't talk about their people. They go against the majority and protect themselves and business interests from the public, from their critics because they've got so many. The two nobles who can relate to people are army officers, [Lord] Ve'ehala and [Lord] 
Fielakepa. They're down-to-earth because they're military and work with ordinary soldiers. Historically, nobles in politics have operated without public buy-in and top-down authoritative rule doesn't work now that government's meant to be more democratic.

Melino Maka: $\quad$ What is a 21st century noble?

Teena Brown Pulu: Exactly; they're having an identity crisis adapting to this century, not the people. The people know it's the 21 st century and not the 19th.

Kalafi Moala: There's Sitiveni Halapua and his kafataha [unity] model for electoral reform. He's on the radio promoting himself and kafataha.

Teena Brown Pulu: Melino made the point to Setita Miller in his TNews interview: why would Steve Halapua promote kafataha [unity] when he can't kafataha [unite] with his party leader 'Akilisi [Pohiva]?

Melino Maka: 'Akilisi [Pohiva] failed to show the country he is the prime minister in waiting. Sitiveni Halapua deliberately tried to sink him. He used 'Akilisi and the Demo's [Democratic Party] to advance his own political career. Halapua had a separate agenda from his party leader and the party; that was to be prime minister with [Lord] Fakafanua as his noble deputy after the vote of no confidence in the PM [prime minister in 2012]. Halapua and [Lord] Fakafanua thought [Prime Minister Lord] Tu'ivakano was going to lose the vote [of no confidence], and they would take over government.

Kalafi Moala: From the alliances formed for this year's election, the independent candidates and parties coming to the fore, it's all top-down political ideology. The same old mind-set that power is exercised over the people; once we're elected we will govern over the people. I can't see any new formations which stand with the people and truly represent the working class, the underclass, the poor, the people from below, which is the majority of Tonga. In all honesty, it's only 'Akilisi 
[Pohiva] who's remained true to his democratic principles that the common people will have a government that represents their interests and works to serve them.

Melino Maka: $\quad$ Political parties aren't the way Tonga's system works. The majority of candidates running for parliament are independent. The independents are the balance of power and if you're a party, you've got to be looking to endorse independent candidates who align with your policies, and be willing to work in coalition government.

Sefita Hao'uli: $\quad$ The political message has to resonate clearly to the public; what is it that is unique, and how does this kind of democracy differentiate itself from others who are also calling on reform? We haven't had to do this before in Tonga; head into an election where the proliferation of candidates and parties has increased because people are wanting change, reform, a different structure and set of expectations around the role of government. If we look at Tongan voters today, there's a wider selection of interests, political ideologies, social values in every constituency and that is reflected in the range of candidates. In seven months the opposition party has to set out its major difference from the presiding government. There is a disconnection between the voters and the major issues affecting the country because the majority have given up on government.

Melino Maka: Revive the economy; any new government has to set that down as the number one priority for Tonga. Two years ago, Teena and I put a trade export plan to the parliamentary committee for agriculture on new markets in New Zealand for crushed chilli and sundried tomato. Ideal for Tonga because the commodities went straight through New Zealand biosecurity. Nothing happened; they didn't do a thing with it. I decided to do it myself and organise women growers in the districts to grow chilli on quarter-acre plots. We'd crush it in Tonga for export to New Zealand, and pay the women cash on delivery. 
Sefita Hao'uli: Then the question is what should government do? Make life more enjoyable? A narrative has to emerge from how government can do that. The turnover that we need to see is the age group of those in their thirties and forties entering parliament. This is the change the country needs because Tonga has a young population with an average age of twenty one. A way to encourage the younger generation into a political career is to have a youth wing of various parties. This could be incorporated into a twenty year national plan; that as a country, Tonga supports younger politicians and women politicians.

Melino Maka: Fakafanua needs to be challenged about being anti-women's seats. If that's his political stance, that he doesn't support women's seats in parliament, then why promote the women's practice parliament the speaker's office is hosting; his office. It's hypocritical.

Kalafi Moala: The nobles are supporting women in parliament because it's a tactic to justify why they should have their nine nobles' seats.

Teena Brown Pulu: Melino's right to say Fakafanua has double-standards. He doesn't support a quota system for women, but he's there on a quota system for nobles. (Brown Pulu, 2014a).

\section{'Scrapping over who should be the prime minister'}

For the remaining days of December 2010 after Lord Tu'ivakano was elected prime minister on Tuesday the $21 \mathrm{st}$ under Tonga's reformed version of a democratic system, Lord Ma'afu embarked on a special task. He assumed the role of an influencer, a job suited to Ma'afu who was a senior noble politician with the gift-of-the-gab. An Irish saying, gift-of-thegab meant that he was talkative, eloquent, and skilled at political persuasion. His post-election thoughts had convinced local and international media into believing what he told them 
at face-value, no questions asked. Whether Ma'afu's word was credible according to Tongan public opinion in respect that voters doubted the nobility were dedicated to democratic change, the media did not consider important enough to query. Journalists reporting in Tonga, New Zealand, and Australia had constructed Ma'afu as the nobles' voice informing the public of what his class group were up to as a political party.

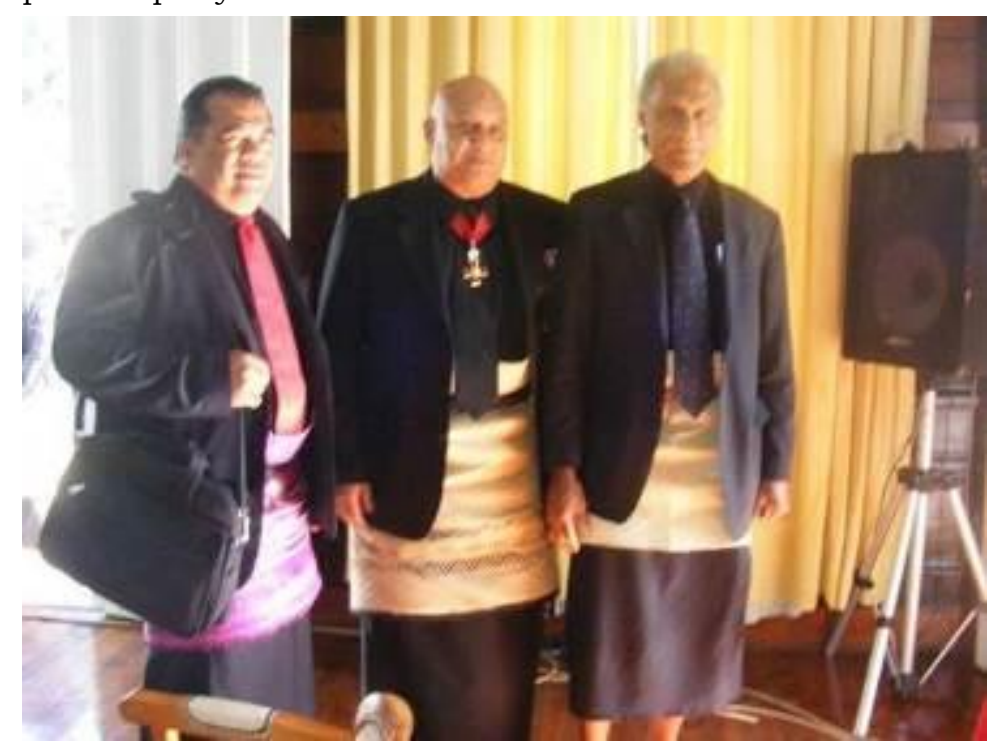

Tonga Minister for Lands, Lord Ma'afu (centre), and 'Akilisi Pohiva (right), leader of the Democratic Party of the Friendly Islands at parliament, 2013. (Photograph by the Parliament of Tonga).

The messages Ma'afu fed the media compared to the mission he was on concealed from public view, exposed his agenda as conflicted and befuddling. He was stuck between a rock and a hard place grappling to draw the line on where the political stopped and the personal started. In the end, political 
and personal got tangled into one and the same, which made it difficult for Tongans to read, understand, and trust what the nobility was planning in private discussion.

Outwardly Ma'afu stated to media that his class group would "support" the legislature's election of a commoner prime minister, namely 'Akilisi Pohiva who was his patrilineal uncle (Dorney, 2010b). In reality he recruited support among parliamentarians to secure Lord Tu'ivakano's election as premier, and was a key talker to convince the initial cabinet ministers to form a government under Tu'ivakano's leadership. Bluntly his speech and actions were duplicitous, but not without individual cause in the sense it was conceivable the nobles would contest, by whatever means they had at hand, to stay in power.

Cited below are post-2010 election comments tracing the migration of Ma'afu's media communication. At first he endorses 'Akilisi Pohiva for premier, and then swings full-circle instructing the Tongan public to "put aside emotions and accept the outcome of the [parliamentary] election" which saw Lord Tu'ivakano in the prime minister's seat (Latu, 2010a). His justification for a noble premier over a commoner is "there are lots of issues that we need to look at within a short amount of time, and so the foundation has to be solid" (Latu, 2010a). What was inferred is that the nobles were the foundation of Tongan government not the newcomer commoners and democratic values.

The composition of cabinet, the "foundation [that] has to be solid" by Ma'afu's testimony, turned out to be a far cry from sturdy (Latu, 2010a). From its inception, the cabinet Ma'afu attempted to consolidate had been hastily assembled on volatile ground. The trip-wire was a misguided logic that the commoners would naturally fall into line behind a noble prime minister in tow with a noble minister for lands. As it happened, four original cabinet ministers who were members 
of the Democratic Party, 'Akilisi Pohiva, Sunia Fili, 'Uliti Uata, and 'Isilelei Pulu, resigned from the Tu'ivakano government maintaining they could not work under the noble-led regime.

Why was that? An obvious and overlooked factor was the deliberate deception laced in the media communication wielded by noble politicians. At the onset, the nobility surreptitiously pushed for a government headed by Tu'ivakano to contest 'Akilisi Pohiva's Democratic Party for the country's leadership. Given a political alliance had been drawn between independent people's representatives wanting to organise an alternative government with the nobles' representatives, one that restrained the Democratic Party to the opposition seats, why the clandestineness rather than open-handed competition? In retrospect that Tu'ivakano took the premier's election by a narrow two-vote margin, 14 to 12 , why would Ma'afu not "see any problem for us to move forward?" (Latu, 2010a).

There are some issues that the nobles will actually want to compromise with, with the new government or the new prime minister, and we will support him if he takes into consideration our concern. (Lord Ma'afu cited in Dorney, 2010b).

The only way forward for Tonga is for parties to work together and not scrapping over who should be prime minister is a good start. (Lord Ma'afu cited in Pamatatau, 2010).

It would have to come from the people. It's their choice. His majesty has agreed to surrender most of his influence and rightly so it should come from the people's representatives. (Lord Ma'afu cited in Dorney, 2010a).

Maybe we are the right people. There are some of us who are very well qualified for the job. But now it's not the right 
time. It's probably the right time for the people to front up [because this] will show the King gave up his power. There are signs the nobles want to compromise. All that matters to us nobles is the welfare of the community - it's really about looking after the community. (Lord Ma'afu cited in Latu, 2010b).

Commoners will dominate [the Cabinet]. From the 17 [people's representatives] I think we have a good collection, and then some good choices can be made from them. Well, that was my personal opinion, and although amongst us nobles we've brought up concerns and we have our differences, in the end we have to stand together. Look, if we put aside emotions and accept the outcome of the election, I don't see any problem for us to move forward. There are lots of issues that we need to look at within a short amount of time, and so the foundation has to be solid. (Lord Ma'afu cited in Latu, 2010a).

Tonga's democratic arrangement reflected partisan politics, or a multiple party system. In context, the opposition party in parliament drove their baseline principle of advocating for the commoner class, which abruptly positioned them as rivals to the nobility. Conversely, the independent people's representatives fashioned an alliance with the nobles to acquire power by securing ministerial posts under a noble prime minister. However, the mind-set of the nobles' representatives remained fixed to the past political system of their forefathers. Collectively, their attitude showed they expected the commoners to bow and scrape to their superior social status by not making concessionary demands of them in forming a coalition government.

Sunia Fili, a people's representative and Democratic Party member, along with Lord Lasike, a nobles' representative terminated from his parliamentary post over a court conviction for possession of firearm ammunition, illuminated this point. 
Remarking on the speech making by Democratic Party parliamentarians in favour of their party leader 'Akilisi Pohiva at the prime minister's election, Fili and Lasike thought the political communication to be relentless to the point of enraging the nobility.

I think the speeches that day made the nobles angrier. (Sunia Fili cited in Maama, 2010).

That's what we lthe nobles with the independent people's representatives were] trying to do, appealing to them to join us on our proposal. Instead they [tried] to raise their voice one after the other, demanding us to join them. (Lord Lasike cited in Maama, 2010).

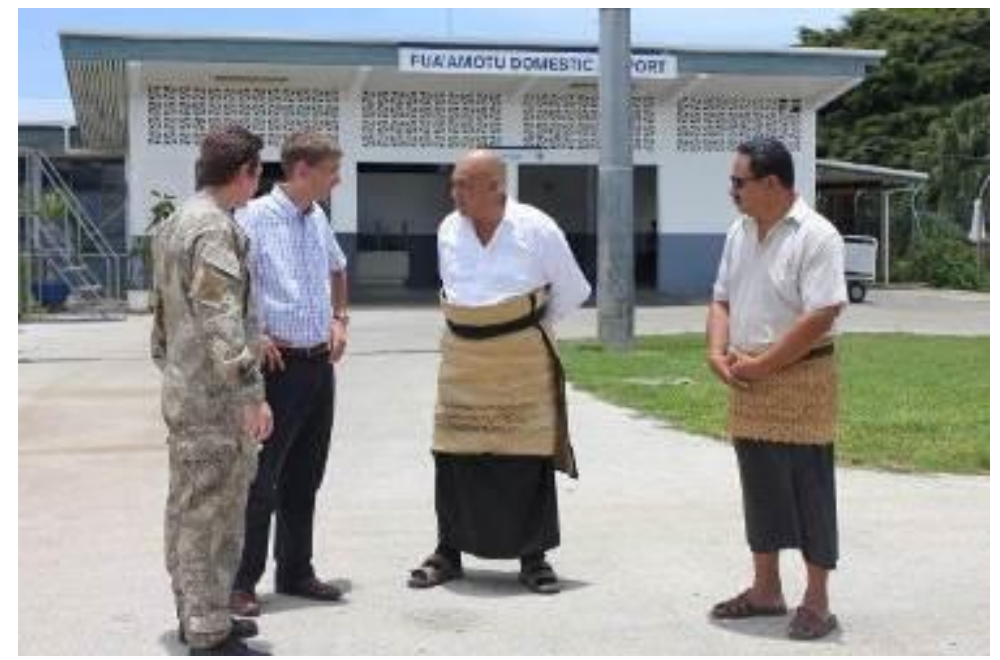

Tonga Minister for Lands, Lord Ma'afu (3rd from left), speaking with New Zealand High Commissioner to Tonga, Mark Talbot (2nd from left) upon receiving New Zealand aid supplies for Ha'apai cyclone victims at Fua'amotu 


\section{Domestic Airport, January 2014. (Photograph by Radio and Television Tonga).}

On the election evening of November 25th 2010, Kalafi Moala reported from Nuku'alofa for the weekly Television New Zealand programme Tagata Pasifika. Special coverage of Tonga's general election under the democratised system was televised live. Moala was optimistic there would be "a very strong pro-democracy government" led by 'Akilisi Pohiva (Kailahi, 2010). His prediction never happened and not without stinging dissatisfaction surfacing among the Democratic Party parliamentarians and their supporters in Tonga and the New Zealand, Australian, and American diaspora.

The people of Tonga have spoken and they want a very strong pro-democracy government. We're looking at about eleven seats that will be belonging to the 'Otu Motu 'Anga Party [Democratic Party] and that's a total change to parliament and they will have the strength to be able to nominate and actually elect the prime minister and most of the cabinet members. Most likely, actually he ['Akilisi Pohiva] will be the next prime minister. He gave an interview a couple of days ago to Radio Australia in which he says, I want to be the prime minister. When he was asked whether he was ready for it, he said yes, obviously yes. If the majority of Tongan people came together and they voted in the majority of pro-democracy or 'Akilisi Pohiva's party to get in, obviously they think we're ready for this kind of thing, and I believe they need to be given a chance. They will be in government and we need to see how they will perform in this next term. (Kalafi Moala cited in Kailahi, 2010). 


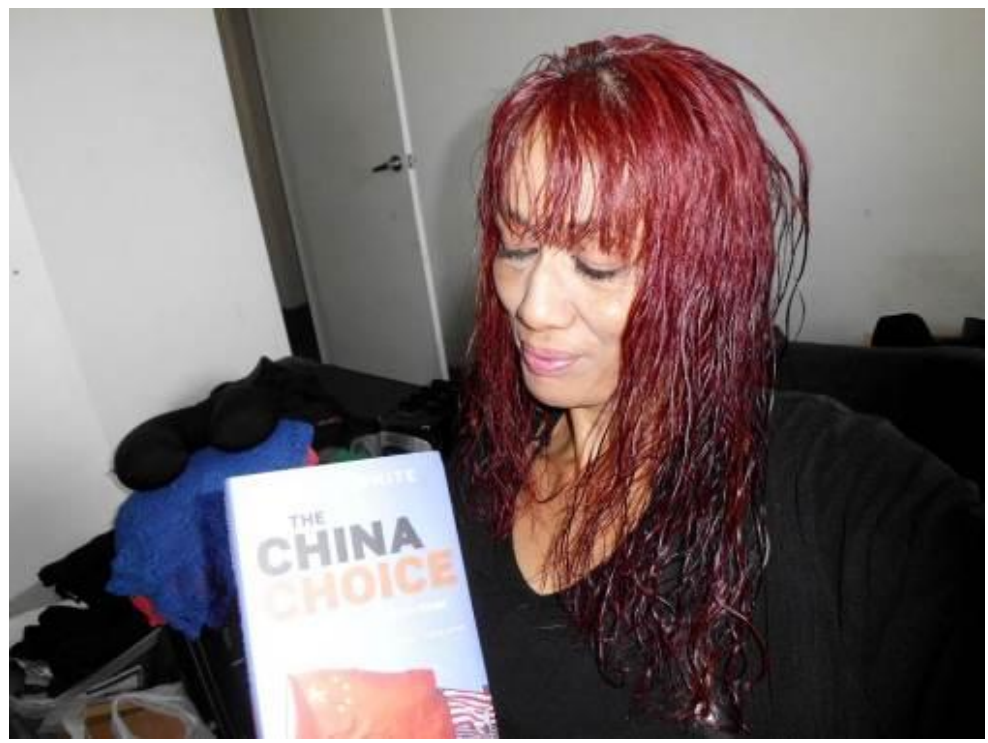

Teena Brown Pulu, author of the essay series development dialogues with Sefita Hao'uli, Kalafi Moala, and Melino Maka at her home office in Auckland where she penned the articles, 2014.

If I had to suggest why Kalafi had returned to 'Akilisi Pohiva's side as an avid supporter for his re-election to parliament in November 2014, coupled with a bid for the premiership and a Democratic Party led government, then I would say nostalgia. It was not entirely that Pohiva had campaigned for democracy in Tonga as a people's representative for twenty eight years that appealed to Kalafi's social consciousness. Nor was it the fact that Pohiva was the former publisher of Kale'a, a pro-democracy newspaper in a local industry of which Kalafi was an established media operator. In all honesty, they had been unfairly sentenced to thirty-days' imprisonment without trial by Tonga's legislature eighteen years ago. This part of their lived experience 
mattered and was intertwined, not merely for the suffering and wrongdoing they endured at the hands of the state, but rather, because together with Filokalafi 'Akau'ola they changed the course of modern history. Here were three ordinary men with extraordinary courage; three commoners of the Kingdom of Tonga who stood up to an autocratic power structure and won out.

'Akilisi Pohiva predicted on election day in 2010 that "the beginning of a new era" was fraught with barbs and hooks for getting a pro-democracy government instated (Dorney, 2010a). Speaking to Australian journalist Sean Dorney, he observed that the "small group of nobles who are not democratically elected" were an obstructive force to structural change (Dorney, 2010a).

Today marks the end of the old order and the beginning of a new era. The most unfortunate thing is that we still have that small group of nobles inside the new structure who are not democratically elected. ('Akilisi Pohiva cited in Dorney, 2010a).

What was different for Tonga colliding head-first into the 2014 election of November 27th? Concisely, the stakes were politically higher. Compounded by intensified social anxiety over national debt and lack of jobs, politicians had to up their game. What had changed for 'Akilisi Pohiva as the leader for the Democratic Party? At seventy-two years old he still came across resolute to fully democratise the Tongan parliament by abolishing the nine reserved seats for nobles and their inhouse election (Moala, 2014b). This second time around, would he be given the same choice to join a coalition government with a different noble premier at the helm? Bearing in mind that for both sides of the House, the nobles and the people, power and resistance is manufactured by 
structural constraint, this did not present a fair and free choice but rather, the last resort.

For Tongans, being confined and defined by a hierarchical structure played out in the politics of knowing where you stand. Blatantly there was no such thing as a neutral Tongan at this point of making political history. Sefita Hao'uli had urged that reform was the collective responsibility of "every man and woman;" but what this necessitated in practice became clear in the murkiness and messiness of change (Brown Pulu, 2014b). In closing, Tongans were now expected to name their side and be upfront about it.

Politicians who held the cards close to their chest, which covertly they intended to play, were not thought to be ingenious or on the ball. Shrewdness and scheming "behind closed doors" in an unstable climate where voters wanted leaders to prove their trustworthiness and transparency was seen as the underhanded politics of traditional powerbrokers (Hao'uli, 2014). On this final note, the American Tongans had coined a popular expression in exasperation with Tongan politics and politicians; perhaps the masses felt they had put up with enough already. 


\section{References}

Anonymous Informant 1. (2014). Personal Correspondence to Teena Brown Pulu, Auckland, January 30.

Bond, P. (2006). Global Governance Campaigning and MDGs: from top-down to bottom up anti-poverty work. Third World Quarterly, 27 (2): 339-354.

Brown Pulu, T. (2014a). Facebook conversation between 'Ofa Guttenbeil-Likiliki and Teena Brown Pulu, Tonga and Auckland, March 11.

Brown Pulu, T. (2014b). Dialogue on Who Owns Tonga?, Sefita Hao'uli, Kalafi Moala, Melino Maka, and Teena Brown Pulu, Auckland, New Zealand, March 6.

Brown Pulu, T. (2012). Ma'afu's Word is in the Hills: What is a Noble's Role in a Democratised Tonga? Te Kaharoa: The e-Journal on Indigenous Pacific Issues, 5 (1): 138-208.

http:/ / tekaharoa.com/index.php/tekaharoa/article/view/108/69

Dorney, S. (2010a). Tonga moves towards democratic rule. Australian Broadcasting Corporation: Correspondents Report, November 28. Retrieved from

http://www.abc.net.au/correspondents/content/2010/s3078245.htm

Dorney, S. (2010b). Tonga votes in landmark election. Australian Broadcasting Corporation News, Melbourne, Australia, November 25. Retrieved from

http:/ / www.youtube.com/watch?v=VzOTXD8YVHU

Government of Tonga. (2014). Press Release: Kingdom of Tonga Committed to Progressing Gender Equality in the Post-2015 Development Framework. Ministry of Internal Affairs, Nuku'alofa, Tonga, March 19. Retrieved from

http://www.mic.gov.to/news-today/press-releases/4884-kingdom-oftonga-committed-to-progressing-gender-equality-in-the-post2015-development-framework

Government of Tonga. (2011). Press Release: UN Secretary General meets Tonga's Prime Minister in NZ. Prime Minister's Office, Nuku'alofa, Tonga, September 9. Retrieved from

http:/ / www.mic.gov.to/news-today/press-releases/2906-unsecretary-general-meets-tongas-prime-minister-in-nz

Haas, A. (2014a). Support for strong and courageous Tongan women. Tonga NZ Net, Auckland, New Zealand, January 24. Retrieved from

http://www.tonganz.net/home/support-strong-courageous-tonganwomen/ 
Haas, A. (2014b). Speaker Fakafanua, possible January voice of Tonga in Wellington. Tonga NZ Net, Auckland, New Zealand, January 18. Retrieved from

http://www.tonganz.net/home/speaker-fakafanua-possible-januaryvoice-tonga-wellington/

Hao'uli, S. (2014). Facebook post to Teena Brown Pulu, Auckland, New Zealand, March 18.

Hoff, J. (2003). A constructivist bottom-up approach to governance: the need for increased theoretical and methodological awareness in research. In Governance as Social and Political Communication, edited by H. K. Bang. Manchester, United Kingdom: Manchester University Press, Pp. $41-60$.

International Federation of Journalists. (1996). Journalists Kalafi Moala and Filokalafi 'Akau'ola sentenced to 30 days in jail. The Global Network: Defending and Promoting Free Expression, Toronto, Canada, September 20. Retrieved from

http://www.ifex.org/tonga/1996/09/20/journalists_kalafi_moala_and filokalafi/

Jansen, H., Johansson-Fua, S., Hafoka-Blake, B. and 'Ilolahia, G. (2012). National Study on Domestic Violence Against Women in Tonga 2009: Nofo 'A Kainga. Nuku'alofa and Canberra: Ma'a Fafine mo e Famili Incorporated and Australian Government, Australian Agency for International Development, Pp. 1 265.

Kailahi, S. (2010). Tonga Election 2010: Part 2 of 2 on Tagata Pasifika, Auckland and Tonga, November 25. Retrieved from

http://www.youtube.com/watch?v=TQUuUMHDkQg

Kefu, 'A. (2010). Legal Advice: Land Reform for Hereditary Estates, Tonga Crown Law Office, Nuku'alofa, Tonga, August 6.

Latu, J. (2010a). Commoners to dominate Cabinet, says noble. Taimi Media Network, Nuku'alofa, Tonga, December 23. Retrieved from

http://www.taimionline.com/articles/883

Latu, J. (2010b). "Not the time" for noble PM. Taimi Media Network, Nuku'alofa, Tonga, December 1 . Retrieved from

http://www.taimionline.com/articles/292

Lewis, K. R. (2011). Getting the Message: Development Communication Strategies in the Kingdom of Tonga. 
Unpublished Master of Development Studies, Victoria University of Wellington, New Zealand, Pp. 1-146.

Mageo, J. M. (2001). Cultural Memory: Reconfiguring History and Identity in the Postcolonial Pacific. Honolulu, Hawai'i: University of Hawai'i Press.

Maama, F. (2010). Oratory overkill blamed for backfiring on Party. Taimi Media Network, Nuku'alofa, Tonga, December 28. Retrieved from

http://www.taimionline.com/articles/945

Moala, K. (2014a). Inappropriate land-grabs in Tonga. Pacific Politics: Political news and analysis bought to you by the Pacific Institute of Public Policy, Port Vila, Vanuatu, $\quad$ March 17. Retrieved from

http:/ / pacificpolitics.com/2014/03/inappropriate-land-grabs-intonga/

Moala, K. (2014b). A reformist's political agenda. Pacific Politics: Political news and analysis bought to you by the Pacific Institute of Public Policy, Port Vila, Vanuatu, February 28. Retrieved from

http://pacificpolitics.com/2014/02/a-reformists-political-agenda/

Moala, K. (2002). Island Kingdom Strikes Back: The Story of an Independent Island Newspaper - Taimi O Tonga: Foreword by Professor Futa Helu. Auckland, New Zealand: Pacmedia Publishers Limited.

New Zealand Government. (2014). NZ affirms strategic direction with Tonga. The Official Website of the New Zealand Government, Wellington, New Zealand, March $5 . \quad$ Retrieved from

http://www.beehive.govt.nz/release/nz-reaffirms-strategic-directiontonga

Pamatatau, R. (2010). Pro-democracy party in Tonga big winner in elections. Radio New Zealand International: Pacific, November 26. Retrieved from

http:/ / www.radionz.co.nz/international/pacific-news/193924/prodemocracy-party-in-tonga-big-winner-in-general-elections

Parliament of Tonga. (2014). Practice Parliament for Women to boost more female [sic] in politics. Parliament of Tonga: News Room, Nuku'alofa, Tonga, February 13. Retrieved from

http://www.parliament.gov.to/index.php/news-room/latestnews/latest-news-in-english/455-practice-parliament-for-womento-boost-more-female-in-politics 
Practice Parliament for Women in Tonga. (2014a). Post on Facebook Community Page for Practice Parliament for Women in Tonga, Legislative Assembly of Tonga, Nuku'alofa, Tonga, February 27.

Practice Parliament for Women in Tonga. (2014b). Photograph and Post on Facebook Community Page for Practice Parliament for Women in Tonga, Legislative Assembly of Tonga, Nuku'alofa, Tonga, February 21.

Television Tonga. (2014a). Queen Nanasipa'u, Women's role in the family, society, and thecountry in Television Tonga News in English, Tonga Broadcasting Commission, Nuku'alofa, Tonga, February 20. Retrieved from

https:/ / www.youtube.com/watch?v=r1cv5JtXUS8\&list=UUJsRwS1oz5i-0hNUsWU_9w\&feature $=c 4$-overview

Television Tonga. (2014b). Lord Fakafanua, Practice Parliament for Women in Television Tonga News in English, Tonga Broadcasting Commission, Nuku'alofa, Tonga, February 13. Retrieved from

https: / / www.youtube.com/watch?v=FQg6z70epic\&list=UUJsRwS1oz5i-OhNUsWU_9w

Thomson, A. (2009). Tongan Parliament Rejects CEDAW Ratification, Women's Groups React. Human Rights Brief, American University, Washington DC, October 21. Retrieved from

http:/ / hrbrief.org/2009/10/tongan-parliament-rejects-cedawratification-women $\%$ E2\%80\%99s-groups-react/

Tonga Royal Land Commission. (2012). Tonga Royal Land Commission Report by Baron Fielakepa, Tevita Tupou, and Kahungunu Baron-Afeaki. Nuku'alofa, Tonga: Royal Land Commission Office, Pp. $1-284$.

United Nations Human Rights. (2014). Convention on the Elimination of All Forms of Discrimination Against Women, New York, 18 December 1979. United Nations Office of the High Commissioner for Human Rights, New York, USA, March 20. Retrieved from

http://www.ohchr.org/EN/ProfessionalInterest/Pages/CEDAW.aspx

Werbowski, M. (2010). What do Julian Assange and Mikhail Khodorkovsky have in common? Digital Journal, Canada, December 11. Retrieved from

http:/ / digitaljournal.com/article/301320

\section{Photographs}

Melino Maka, Sefita Hao'uli and Kalafi Moala at AUT University, Photograph of Teena Brown Pulu, 2013. 
Lord Fakafanua at the Kolonga consultation, Facebook page for the practice parliament for women in Tonga, 28 February 2014. Prime Minister Lord Tu'ivakano and New Zealand Foreign Minister Murray McCully in Auckland, Radio and Television Tonga, March 2014.

Lord Ma'afu and 'Akilisi Pohiva at parliament, Parliament of Tonga, 2013.

Lord Ma'afu and New Zealand High Commissioner Mark Talbot at Fua'amotu domestic airport, Radio and Television Tonga, January 2014.

Teena Brown Pulu at her home office in Auckland, Photograph of Teena Brown Pulu, 2014. 